\title{
Kinase inhibitors for the treatment of inflammatory and autoimmune disorders
}

\author{
Shripad S. Bhagwat
}

Received: 4 April 2008 / Accepted: 13 May 2008 / Published online: 21 June 2008

(C) Springer Science + Business Media B.V. 2008

\begin{abstract}
Drugs targeting inhibition of kinases for the treatment of inflammation and autoimmune disorders have become a major focus in the pharmaceutical and biotech industry. Multiple kinases from different pathways have been the targets of interest in this endeavor. This review describes some of the recent developments in the search for inhibitors of IKK2, Syk, Lck, and JAK3 kinases. It is anticipated that some of these compounds or newer inhibitors of these kinases will be approved for the treatment of rheumatoid arthritis, psoriasis, organ transplantation, and other autoimmune diseases.
\end{abstract}

Keywords Kinase inhibitors · Anti-inflammatory agents · Autoimmune modulators · IKK2 inhibitors · Syk inhibitors · Lck inhibitors · JAK3 inhibitors

\section{Introduction}

Discovery of novel drugs targeting kinases, an important class of intracellular enzymes that play a critical role in signal transduction pathways controlling a variety of cellular functions, has become the focus of a large number of drug discovery programs in the pharmaceutical and biotech industry. The role of a kinase in signal transduction is to catalyze the transfer of the terminal phosphate group of ATP to an appropriate substrate leading to the activation of the substrate for its role in the next step of the signaling cascade. The substrate is often another kinase or a

S. S. Bhagwat $(\square)$

Ambit Biosciences,

4215 Sorrento Valley Boulevard,

San Diego, CA 92121, USA

e-mail: sbhagwat@ambitbio.com transcription factor. A large majority of kinase inhibitors are designed to inhibit the enzyme by binding at or near the ATP-binding site. Therefore, an inhibitor of one kinase is often found to inhibit other structurally related or unrelated kinases. This inherent promiscuity of kinase inhibitors calls for extensive profiling of the inhibitors either for driving structure-activity relationship (SAR) during lead optimization or for opportunistic discoveries [1,2].

Currently eight small molecule kinase inhibitor drugs and a handful of protein/antibody therapeutics targeting kinases have been approved for human use. A large number of kinase inhibitor discovery programs have been focused on drugs for the treatment of inflammation and autoimmune disorders; however, the approved drugs to date have been useful for the treatment of a variety of cancers in humans. One of the reasons cited for this lack of success to date for kinase inhibitor drugs for the treatment of patients with inflammation and autoimmune disorders has been the high hurdle for safety required for the chronic treatment of patients whose life expectancy is usually significantly longer than that of cancer patients.

A large number of kinases from different signal transduction pathways have been the targets of interest for the treatment of inflammation and autoimmune disorders. One class of such kinases have been the mitogen-activated protein kinases (MAP kinases), which has been summarized in a recent review [3], and hence will not be covered in this chapter. This review will cover the recent publications, primarily from 2006-2007, describing inhibitors of IKK2 (IкB kinase 2), Syk (spleen tyrosine kinase), Lck (lymphocyte-specific kinase), and JAK3 (Janus kinase 3). Inhibitors of kinases such as BTK and Fyn are not covered in this review. Some of the publications cited in this review refer to the inhibitors reported earlier for that kinase. A large number of patents on kinase inhibitors describe, 
sometimes with very little, if any, information on the biological profile of compounds. This chapter will not cover such disclosures. Additionally, a majority of kinase inhibitors disclosed as having inhibitory activity for one kinase are found to be potent inhibitors of other kinases. This review will focus on the kinase inhibitors that are profiled for a particular kinase with potential application in inflammation. The inhibitors described for certain kinases, such as Src family kinases, that inhibit other kinases relevant to inflammation, but are not profiled for antiinflammatory activity, are not included in this review.

\section{IKK2 inhibitors}

Nuclear factor (NF)- $\mathrm{KB}$ is an important transcription factor that regulates multiple cell functions. This transcription factor exists in the cytoplasm in an inactive form because of its binding to the inhibitory protein, IKB. Upon activation of the cell following the binding of cytokines and growth factors or by UV or stress, a signal transduction cascade unravels that leads to the activation of the serine-threonine kinases, IKK1 and IKK2. IKK2 phosphorylates the Ser32 and Ser36 residues of IKB bound to NF-kB. The phosphorylated complex is ubiquitinated by E3RS ligase and degraded by proteasome to generate the active NF- $k B$. The transcription factor then translocates to the nucleus and induces the transcription of proinflammatory cytokines and matrix metalloproteases [4]. Inhibition of IKK2 has been pursued as a potential therapy to treat disorders related to inflammation and autoimmunity. Based on the critical role of NF- $\mathrm{KB}$ in the immune system and on the data from knockout mice, it has been postulated that chronic inhibition of this transcription factor could lead to opportunistic infections and hepatic toxicity. However, studies in transgenic mice and of some of the inhibitors in animals have indicated that inhibition of NF- $\mathrm{kB}$ function is unlikely to cause systemic infection and apoptosis of hepatic tissue in animals [5].

The IKK2 inhibitors discussed herein are shown in Fig. 1. BMS-345541 is reported to be a selective and ATPnoncompetitive inhibitor of IKK2 with $\mathrm{IC}_{50}=300 \mathrm{nM}$ [6]. The compound was not a potent inhibitor of IKK1 $\left(\mathrm{IC}_{50}=\right.$ $4 \mu \mathrm{M}$ ). In lipopolysaccharide (LPS)-stimulated THP-1 cells, the expression of proinflammatory cytokines such as interleukin (IL)-1 $\beta$, IL-6, and tumor necrosis factor alpha (TNF- $\alpha$ ) was inhibited with $\mathrm{IC}_{50}=1-5 \mu \mathrm{M}$. At a dose of $30 \mathrm{mg} / \mathrm{kg}$ administered once daily, BMS-345541 maximally reduced disease severity in a murine model of dextran sulfate sodium-induced colitis [7]. The compound dosed at $100 \mathrm{mg} / \mathrm{kg}$ (po, qd) in this model showed a similar benefit. Structural modification of BMS-345541 has resulted in compounds 1-3, which are significantly more potent inhibitors of IKK2 with $\mathrm{IC}_{50}=10-60 \mathrm{nM}$ [8]. In LPSstimulated THP-1 cells, compound 1 inhibited TNF- $\alpha$ production with $\mathrm{IC}_{50}=0.34 \mu \mathrm{M}$, while BMS-345541 was less potent in this test with $\mathrm{IC}_{50}=4 \mu \mathrm{M}$. Oral administration of compound 1 to mice inhibited the LPS-induced TNF- $\alpha$ levels in the serum with $\mathrm{ED}_{50}=10 \mathrm{mg} / \mathrm{kg}$. A structurally related, imidazo-thieno-pyrazine derivative, $\mathbf{4}$, has been reported to inhibit IKK2 with $\mathrm{IC}_{50}=13 \mathrm{nM}$ and IKK1 with $\mathrm{IC}_{50}=390 \mathrm{nM}$ [9]. A $10 \mathrm{mg} / \mathrm{kg}$ oral administration of 4 to mice, $1 \mathrm{~h}$ prior to LPS challenge, inhibited TNF- $\alpha$ levels by $50 \%$. However, administration of $4,4 \mathrm{~h}$ prior to LPS challenge, did not inhibit TNF- $\alpha$ levels, indicating that the compound has a short half-life.

A series of 2-anilino-4-arylpyrimidines such as compound $\mathbf{5}$ have been reported to be potent IKK2 inhibitors with $\mathrm{IC}_{50}=11 \mathrm{nM}$ for compound 5 [10]. The authors have not disclosed cellular and in vivo activity profiles of the compounds and have attempted to explain the SAR using a homology model of IKK2 and using quantitative structureactivity relationship (QSAR) models.

In a series of publications, Murata and coworkers have disclosed optimization of substituted pyridines to identify compound 6 with IKK2 $\mathrm{IC}_{50}=8.5 \mathrm{nM}$ [11-13]. Compound 6 was a poor inhibitor of IKK1 with $\mathrm{IC}_{50}=250 \mathrm{nM}$. Compound 6 inhibited LPS-induced TNF- $\alpha$ production in human PBMCs (peripheral blood mononuclear cells) with $\mathrm{IC}_{50}=50 \mathrm{nM}$. Oral administration of $0.3-3 \mathrm{mg} / \mathrm{kg}$ of compound 6 inhibited the arachidonic acid-induced ear edema in mice in a dose-dependent manner. The antiinflammatory activity of 6 at $1 \mathrm{mg} / \mathrm{kg}$ oral dose in this model was superior to that of dexamethasone at $0.3 \mathrm{mg} / \mathrm{kg}$ oral dose. The oral bioavailability of $\mathbf{6}$ in rats was $60 \%$ with low clearance ( $\mathrm{CL}=0.33 \mathrm{l} / \mathrm{h}$ per $\mathrm{kg}$ ). Compound 7 has been reported to be a potent, ATP-competitive, and moderately selective inhibitor of IKK2 with $\mathrm{K}_{\mathrm{i}}=2 \mathrm{nM}$ [14]. The compound inhibited the cytokines and other inflammatory mediators in a variety of cells upon induction $\left(\mathrm{IC}_{50}=47 \mathrm{nM}\right.$ for LPS-induced TNF- $\alpha$ production in PBMCs). Compound 7 had good bioavailability in rats and mice and showed beneficial effects in animal models of allergy, lung inflammation, edema, and delayed-type hypersensitivity (DTH).

Structural modification of SC-415, a known weak but selective IKK2 inhibitor [15], has yielded compound $\mathbf{8}$ and analogs with modest IKK2 inhibitory potency [16]. Compound 8, with $\mathrm{IC}_{50}=333 \mathrm{nM}$ for inhibition of IKK2, inhibited IL-8 production in IL-1 $\beta$-stimulated synovial fibroblasts derived from rheumatoid arthritis patients with $\mathrm{IC}_{50}=832 \mathrm{nM}$.

A structurally related compound TPCA-1 has been reported to be an ATP-competitive and selective inhibitor 
<smiles>Cc1ccc2nc(NCCN)c3ncc(C)n3c2c1</smiles>

BMS-345541<smiles>CNc1nc2cc3ccccc3cc2n2c(O)cnc12</smiles>

1<smiles>CNCCNc1nc2cc3ccccc3cc2c2c(C)cnn12</smiles>

2<smiles>CNc1nc2cc(-c3cccc(CCNCC(N)=O)c3)sc2n2c(C)cnc12</smiles>

3

4<smiles>N#Cc1c(C2CCNCC2)cc(-c2c(O)cccc2OCC2CC2)nc1N</smiles><smiles>O=C1Nc2nc(-c3c(O)cccc3OCC3CC3)cc(C3CCCNC3)c2CO1</smiles><smiles>NC(=O)c1sc(-c2ccsc2)cc1N</smiles><smiles>NC(=O)Nc1sc(-c2ccc(F)cc2)cc1C(N)=O</smiles>

TPCA-1<smiles>N#Cc1cc(C#Cc2cc(C(N)=O)c(NC(N)=O)s2)cs1</smiles>

8<smiles>O=C(c1ccc(Nc2nccc(-c3cc4ccccc4s3)n2)cc1)N1CCC(N2CCCC2)CC1</smiles>

10<smiles>NC(=O)Nc1cc(-c2ccc(F)cc2)sc1C(N)=O</smiles>

9<smiles>O=C(Nc1cc(Cl)cc2c1[nH]c1cnccc12)c1cccnc1</smiles>

PS-1145

Fig. 1 IKK2 inhibitors

of IKK2 with $\mathrm{IC}_{50}=18 \mathrm{nM}$ [17]. The production of cytokines such as TNF- $\alpha$, IL-6, and IL-8 induced by LPS in human PBMCs was inhibited by TPCA-1 with $\mathrm{IC}_{50}=$ $170-320 \mathrm{nM}$. A $20 \mathrm{mg} / \mathrm{kg}$ oral dose of TPCA-1 administered twice daily to mice significantly reduced the clinical score and disease severity in a collagen-induced arthritis (CIA) model. Compound $\mathbf{9}$, an isomer of TPCA-1, has been reported to be a potent inhibitor of IKK2 with $\mathrm{IC}_{50}=63 \mathrm{nM}$ and 100-fold selective over IKK1 [18]. In PBMCs, the LPS-induced TNF- $\alpha$ production was inhibited by 9 with $\mathrm{IC}_{50}=400 \mathrm{nM}$. The compound showed low in vitro metabolic clearance in rat hepatocytes, low in vitro plasma protein binding, and good oral bioavailability $(\% \mathrm{~F}=78$ in rats).

An anilinopyrimidine derivative, 10, has been reported to be a potent $\mathrm{IKK} 2$ inhibitor with $\mathrm{IC}_{50}=40 \mathrm{nM}$ [19]. In human vascular endothelial cells (Huvec), 10 inhibited the TNF- $\alpha$-induced expression of the adhesion molecules ICAM- 1 and VCAM-1 with $\mathrm{IC}_{50}=300 \mathrm{nM}$. Administration of $30 \mathrm{mg} / \mathrm{kg}$ oral dose of $\mathbf{1 0}$ inhibited TNF- $\alpha$ release by $75 \%$ upon LPS challenge in rats. Compound 10 exhibited anti-inflammatory activity in a thioglycollate-induced peritonitis model in mice. At a dose of $10 \mathrm{mg} / \mathrm{kg}$ s.c. (subcutaneous), $\mathbf{1 0}$ inhibited neutrophil extravasation by $50 \%$ in this model.

SPC-839, whose structure is undisclosed, has been reported to be a potent and selective IKK2 inhibitor $\left(\mathrm{IC}_{50}=20 \mathrm{nM}\right)$ with a significant oral anti-inflammatory activity in an adjuvant-induced arthritis model in rats [20]. The compound has been licensed to Serono and the publications from this company disclose this compound as AS602868 which is an anilinopyrimidine derivative [21]. 
PS-1145 has been reported to be a potent IKK2 inhibitor with $\mathrm{IC}_{50}=100 \mathrm{nM}$ [22]. The compound inhibited the phosphorylation of the endogenous IKK complex in cell lysates from TNF- $\alpha$-induced HeLa cells with $\mathrm{IC}_{50}=$ $150 \mathrm{nM}$. PS- 1145 , at an oral dose of $50 \mathrm{mg} / \mathrm{kg}$, inhibited LPS-induced TNF- $\alpha$ levels in mice by $60 \%$.

\section{Syk inhibitors}

Spleen tyrosine kinase (Syk) is a cytosolic protein tyrosine kinase that plays a crucial role in the $\operatorname{IgE}(\mathrm{Fc \varepsilon RI})$ and $\operatorname{IgG}$ $(\mathrm{Fc} \gamma)$ receptor-mediated signaling in mast cells, basophils, and macrophages leading to degranulation and cytokine release that contribute to proinflammatory and allergic responses. In addition, activation of Syk is involved in Bcell receptor signaling as well as Fc receptor-mediated antigen presentation. A variety of experimental evidence points to the potential use of Syk inhibitors in the treatment of various autoimmune disorders [23].

Figure 2 shows the structure of Syk inhibitors discussed below. The oxindoles 11a and 11b have been reported to inhibit Syk with $\mathrm{IC}_{50}=20$ and $145 \mathrm{nM}$, respectively [24]. The degranulation of rat basophilic cells (RBL-2H3), induced by $\operatorname{IgE} / \mathrm{Fc} \varepsilon \mathrm{RI}$, was inhibited by $\mathbf{1 1 a}$ and $\mathbf{1 1 b}$ with $\mathrm{IC}_{50}=110$ and $100 \mathrm{nM}$, respectively.

Compound 12 and analogs have been reported to be potent inhibitors of Syk with no additional data in cells or animals $\left(\mathrm{IC}_{50}=8 \mathrm{nM}\right.$ for 12) [25].

BAY 61-3606 has been reported to be an ATPcompetitive and selective inhibitor of Syk with $\mathrm{IC}_{50}=$ $10 \mathrm{nM}$ [26]. The degranulation of the RBL-2H3 cell line was inhibited with $\mathrm{IC}_{50}=46 \mathrm{nM}$. In an ovalbumin-induced airway inflammation model in the rat, the efficacy of BAY 61-3606, at a dose of $30 \mathrm{mg} / \mathrm{kg}$, b.i.d., in suppressing the accumulation of eosinophils in BAL fluid was similar to that of $0.3 \mathrm{mg} / \mathrm{kg}$ po, b.i.d., of dexamethasone. The less than adequate pharmacokinetic profile of BAY 61-3606 (low AUC and fast elimination half-life) contributed to the need for the high dose in rats for efficacy of this potent inhibitor of Syk.

Compound 13 has been reported to be a potent and selective Syk inhibitor with $\mathrm{IC}_{50}=41 \mathrm{nM}$ [27]. The compound inhibited the degranulation of RBL-2H3 cells (as measured by release of serotonin) with $\mathrm{IC}_{50}=460 \mathrm{nM}$ and inhibited the IgE-induced passive cutaneous anaphylaxis reaction in mice with $\mathrm{ED}_{50}=13.2 \mathrm{mg} / \mathrm{kg}$ s.c.

R112 and R406, two structurally related analogs, have been reported to be potent, selective, and ATP-competitive inhibitors of Syk. R112 inhibited Syk enzyme activity with $\mathrm{K}_{\mathrm{i}}=96 \mathrm{nM}$ and inhibited anti-IgE-mediated histamine release from primary human basophils with $\mathrm{EC}_{50}=$ $280 \mathrm{nM}$ [28]. In a phase II study in normal volunteers with seasonal allergic rhinitis, intranasally delivered R112 significantly reduced clinical symptoms such as stuffy, itchy, and runny nose, sneezes, cough, and headache [29]. R406 inhibited Syk with $\mathrm{K}_{\mathrm{i}}=30 \mathrm{nM}$ and inhibited anti-IgEinduced degranulation and production and release of leukotrienes, cytokines, and chemokines from cultured human mast cells with $\mathrm{EC}_{50}=40-160 \mathrm{nM}$ [30]. In a CIA model in rats, a $30 \mathrm{mg} / \mathrm{kg}$ oral b.i.d dose of R406, or a water-soluble prodrug, R788, completely suppressed symptoms of inflammation and regressed arthritic score including joint destruction [31]. In healthy human volunteers, orally administered R406 was well tolerated, exhibited desirable pharmacokinetic properties, and inhibited baso-<smiles>[X]c1ccc2c(c1)/C(=C/c1cn(C)c3ccc(OC)cc13)C(=O)N2</smiles>

11a : $\mathrm{X}=\mathrm{SO}_{2} \mathrm{NHMe}$ 11b : $\mathrm{X}=\mathrm{CONHMe}$<smiles>NCCCNc1nc(-c2ccc(N3CCOCC3)cc2)cc2ncccc12</smiles>

12<smiles>COc1ccc(-c2cc3nccn3c(Nc3ncccc3C(N)=O)n2)cc1OC</smiles>

BAY 61-3606<smiles>NCCNc1ncc(C(N)=O)c(Nc2cccc(C(F)(F)F)c2)n1</smiles>

13<smiles>Oc1cccc(Nc2ncc(F)c(Nc3cccc(O)c3)n2)c1</smiles>

R112<smiles>COc1cc(Nc2ncc(F)c(Nc3ccc4c(n3)NC(=O)C(C)(C)O4)n2)cc(OC)c1OC</smiles>

R406

Fig. 2 Syk inhibitors 
phil activation and degranulation induced ex vivo by $\operatorname{IgE}$ in a dose-dependent manner.

\section{Lck inhibitors}

The lymphocyte-specific kinase (Lck), belonging to the Src family of tyrosine kinases, is expressed in $\mathrm{T}$ cells and natural killer (NK) cells and is responsible for the activation of and signaling through the T-cell receptor. Activation of this cascade results in the upregulation of inflammatory cytokines such as IL-2 and interferon (IFN)- $\gamma$, and ultimately in the activation and proliferation of $\mathrm{T}$ lymphocytes to generate an immune response. Therefore, inhibition of Lck is likely to elicit an immunosuppressive effect that could be useful in the treatment of T-cell-mediated diseases like rheumatoid arthritis, inflammatory bowel disease, psoriasis, and organ graft rejection [32]. A large number of compounds are reported to be potent inhibitors of Lck (see reference 5 in reference [44] in this review). This review will focus on the Lck inhibitors reported primarily in the years 2006-2007 and these publications refer to the earlier reports on Lck inhibitors. There are a number of disclosures of Src or Src family inhibitors as anticancer agents that have or are likely to have Lck inhibitory activity. Most of these compounds are not covered in this review.

Figure 3 summarizes the structure of Lck inhibitors discussed here. An anilinopyrimidine, 14, has been reported to inhibit Lck with $\mathrm{IC}_{50}=19 \mathrm{nM}$ with a selectivity of 3- to 30 -fold against Btk, Lyn, Syk, and Txk and is proposed to bind in the ATP site of Lck [33]. The pharmacokinetic profile of $\mathbf{1 4}$ was determined to be modest.

A series of 2,3-diaryl-furopyrimidines have been reported to be modestly selective Lck inhibitors [34]. Compound 15 inhibited Lck with $\mathrm{IC}_{50}=98 \mathrm{nM}$ and inhibited anti-CD3/CD-28-induced secretion of IL-2 in T cells isolated from human peripheral blood lymphocytes with $\mathrm{IC}_{50}=430 \mathrm{nM}$. The X-ray structure of a close analog of $\mathbf{1 5}$ in Lck indicated that the compound binds in the ATP site and that the $\mathrm{C}-\mathrm{H}$ at the 2-position donates an $\mathrm{H}$-bond to the carbonyl of Glu317. Compound 16, which is closely related to $\mathbf{1 5}$, is a modestly selective inhibitor of Lck with $\mathrm{IC}_{50}=22 \mathrm{nM}$. The binding mode and H-bonding pattern of this class of furopyridines in Lck is shown to be similar to that of the furopyrimidines [35].

Compound $\mathbf{1 7}$ is reported to be a modestly potent inhibitor of Lck $\left(\mathrm{IC}_{50}=210 \mathrm{nM}\right)$ with significant selectivity against the other members of the Src family of kinases [36]. The compound, which had modest oral bioavailability in rats, inhibited anti-CD3 antibody-induced IL-2 production in mice with $\mathrm{ED}_{50}=5 \mathrm{mg} / \mathrm{kg}$ po. A structurally related compound, A-770041, is an inhibitor of Lck
$\left(\mathrm{IC}_{50}=147 \mathrm{nM}\right)$ with a significant selectivity against other members of the Src family of kinases [37]. The anti-CD3 antibody-stimulated IL-2 production in human whole blood was inhibited by this compound with $\mathrm{IC}_{50}=$ $80 \mathrm{nM}$. A-770041 exhibited a desirable oral pharmacokinetic profile in rats and oral efficacy against heart transplant rejection in a rat model at $10 \mathrm{mg} / \mathrm{kg}$ b.i.d. dosing.

Compound 18 (racemic) is reported to be a potent inhibitor of $\mathrm{Src}\left(\mathrm{IC}_{50}=20 \mathrm{nM}\right)$ and Lck $\left(\mathrm{IC}_{50}=8 \mathrm{nM}\right)$ with protective effects (reduction of infarct size) in a rat model of middle cerebral artery occlusion (MCAO) [38]. A molecular modeling-guided design of Src inhibitors has led to the identification of $\mathbf{1 9}\left(\mathrm{Src} \mathrm{IC}_{50}=28 \mathrm{nM}\right.$ and Lck $\mathrm{IC}_{50}=29 \mathrm{nM}$ ) with efficacy in tumor xenograft models in mice upon intraperitoneal (i.p.) administration [39].

A series of benzimidazole-substituted anilinopyrimidines have been reported to be potent inhibitors of Lck. Compound 20 inhibited Lck with $\mathrm{IC}_{50}=3 \mathrm{nM}$ and inhibited phorbol myristate acetate (PMA)-induced IL-2 production in Jurkat T cells with $\mathrm{IC}_{50}=54 \mathrm{nM}$ [40]. However, the series of compounds seemed to lack specificity against other Src family kinases and lacked desirable pharmacokinetic properties. The pyrimidopyrazine derivative, $\mathbf{2 1}$, is reported to be a potent Lck inhibitor with $\mathrm{IC}_{50}=2 \mathrm{nM}$ [41]. The cellular activity (IL-2 inhibition in T cells), selectivity against other Src family of kinases, and pharmacokinetic properties of $\mathbf{2 1}$ were less than optimal.

The anilinopyrimidine urea, 22, inhibited Lck with $\mathrm{IC}_{50}=87 \mathrm{nM}$ and inhibited the hind paw swelling by $63 \%$ upon oral administration twice a day at $25 \mathrm{mg} / \mathrm{kg}$ in an adjuvant-induced arthritis model in rats [42].

Compound 23, a close structural analog of dasatinib (BMS-354825), a marketed kinase inhibitor drug for the treatment of chronic myelogenous leukemia (CML), is a potent, selective, and ATP-competitive inhibitor of Lck and other Src family kinases $\left(\mathrm{IC}_{50}=1 \mathrm{nM}\right.$ for hLck) [43]. In an ex vivo anti-CD3/CD-28-induced IL-2 production model in mice, orally administered $\mathbf{2 3}$ reduced serum IL-2 levels in a dose-dependent manner with $\mathrm{ED}_{50}=5 \mathrm{mg} / \mathrm{kg}$. Compound 23, which has a desirable pharmacokinetic profile in rats $(\%$ $\mathrm{F}=65$ ), was efficacious in reducing paw swelling upon oral dosing at $3 \mathrm{mg} / \mathrm{kg}$ b.i.d. in a rat adjuvant arthritis model of established disease.

The 2-amino-6-aryl-quinazoline derivative, $\mathbf{2 4}$, is a potent Lck inhibitor $\left(\mathrm{IC}_{50}=0.5 \mathrm{nM}\right)$ that is not selective against other members of Src family kinases, p38, and VEGFR2 [44]. In a human whole blood assay, 24 inhibited the anti-CD3/CD28 antibody-induced IL-2 production with $\mathrm{IC}_{50}=113 \mathrm{nM}$. Compound $\mathbf{2 4}$ had a desirable pharmacokinetic profile in rats $(\% \mathrm{~F}=55)$ and was orally efficacious in reducing serum levels of IL-2 in BALB/c mice with $\mathrm{ED}_{50}=$ $22 \mathrm{mg} / \mathrm{kg}$. 
<smiles>Cc1ccc2[nH]ncc2c1Nc1ccnc(Nc2cccc(C(N)=O)c2)n1</smiles>

14<smiles>COc1ccc(O)cc1Nc1cc(OCCN2CCOCC2)nc(-n2cnc3ccccc32)n1</smiles><smiles>c1ccc(-c2c(-c3ccc(OCCN4CCOCC4)cc3)oc3nccc(NCCN4CCNCC4)c23)cc1</smiles>

16<smiles>Cc1cccc(C)c1Nc1ncc(-c2ccc(OCC3CCCN(C)C3)cc2)n2cncc12</smiles>

18<smiles>Cc1cc(-c2c(Cl)cccc2Cl)cc2nnc(Nc3ccc(OCCN4CCCC4)cc3)nc12</smiles>

19<smiles>CCN(CC)CCOc1ccc(Nc2cc(N(C)C(=O)Nc3c(Cl)cccc3Cl)ncn2)cc1</smiles>

22<smiles>CNc1ncc2cc(-c3cc(C(=O)Nc4cc(C(F)(F)F)ccc4OC4CCN(C)CC4)ccc3C)ccc2n1</smiles>

24

Fig. 3 Lck inhibitors

\section{JAK3 inhibitors}

The Janus kinases, JAK1, JAK2, JAK3, and Tyk2, are cytoplasmic protein tyrosine kinases that play a critical role in the cytokine receptor binding-triggered signal transduction through the STAT (signal transducers and activators of transcription) proteins [45]. Binding of cytokines activates the JAK kinases which phosphorylate and activate the STAT proteins. The STAT proteins form homo- or heterodimers and translocate to the nucleus where they induce<smiles>COc1cc(-c2csc3c(/C=C/CN4CCC(O)CC4)cnc(N)c23)ccc1NC(=O)c1cc2ccccc2n1C</smiles>

17<smiles>COc1cc(-c2nn([C@H]3CC[C@H](N4CCC(C(C)=O)CC4)CC3)c3ncnc(N)c23)ccc1NC(=O)c1cc2ccccc2n1C</smiles><smiles>CCN(CC)CCOc1ccc(Nc2ncc3c(n2)N2CCC(=O)N2C(c2c(C)cccc2C)=C3)cc1</smiles>

21<smiles>Cc1cc(Nc2ncc(C(=O)Nc3c(C)cccc3Cl)s2)nc(C)n1</smiles>

23<smiles>Cc1nc(Nc2ncc(C(=O)Nc3c(C)cccc3Cl)s2)cc(N2CCN(CCO)CC2)n1</smiles>

Dasatinib (BMS-354825)

transcription of proinflammatory genes. JAK3 is expressed at high levels in NK cells and normally in thymocytes, platelets, mast cells, and inducible $\mathrm{T}$ and $\mathrm{B}$ cells. JAK3, which is associated with the cytokine signaling through the $\gamma$ c-chain of the IL-2 receptor, is critical for lymphocyte survival, differentiation, and function. In humans, mutations in JAK3 have been associated with severe combined immunodeficiency (SCID) [46] and JAK3 knockout mice are found to display defects in $\mathrm{T}, \mathrm{B}$, and $\mathrm{NK}$ cell development and function [47]. Therefore, inhibition of 
JAK3 has potential applications in the treatment of inflammation, allergy, autoimmune disorders, and organ transplant rejection [45]. A number of JAK3 inhibitors, such as WHI-P131, WHI-P154, and PNU156804, which are not highly selective against other members of the JAK family of kinases, have been reported and included in a review article [48]. This review will focus on JAK3 inhibitors reported during 2006-2007 and the references cited here refer to the inhibitors reported earlier. A number of JAK3 inhibitors have been disclosed in an abstract, manuscript, or at scientific meetings without disclosing their structure and/or pharmacology profile (for example, R348, an inhibitor of JAK3 and Syk [49]); such inhibitors are not covered in this review.

A selective JAK2 inhibitor could have a potential antiinflammatory effect through the inhibition of the Th1 pathway. However, the reported and available JAK2 inhibitors have some degree of JAK3 inhibitory activity and therefore the observed effect could, at least partly, be due to concomitant JAK3 inhibition. This review will not include the JAK2 inhibitors that are reported to have JAK3 inhibitory activity.

Figure 4 shows the structure of JAK3 inhibitors discussed below. PF-956980, a structurally close analog of CP-690550, has been reported to be a potent and selective inhibitor of JAK3 with $\mathrm{IC}_{50}=4 \mathrm{nM}$ (vs $1 \mathrm{nM}$ for CP690550) [50]. In the human whole blood assay, the anti$\mathrm{CD} 3 / \mathrm{CD} 28$ antibody-stimulated production of IFN- $\gamma$ was inhibited by PF-956980 with $\mathrm{IC}_{50}=121 \mathrm{nM}$, while CP690550 had $\mathrm{IC}_{50}=25 \mathrm{nM}$. The lower potency of PF-956980 in this assay was attributed to its higher protein binding. In a DTH test in mice, PF-956980 when dosed by an i.v. infusion inhibited the sheep red blood cell-induced paw swelling with $\mathrm{EC}_{50}=5 \mathrm{mg} / \mathrm{kg}$.

CP-690550, a potent JAK3 inhibitor with in vitro enzyme inhibitory and cellular activity as described above, is found to inhibit JAK2 kinase significantly [51]. The compound is found to exhibit profound immunosuppressive activity in a variety of animal models [52, 53]. In a CIA model in mice, a $5 \mathrm{mg} / \mathrm{kg}$ per day oral dose of CP-690550 was well tolerated and completely suppressed the clinical score and severity of arthritis [53]. This compound is reported to be efficacious in phase II trials in arthritis and kidney transplantation [54, 55]. In a phase II study in patients with rheumatoid arthritis, treatment with CP690550 at an oral dose of $15 \mathrm{mg}$ b.i.d. for 6 weeks resulted in $54 \%$ of the patients responding with an ACR50 score [54]. The compound was not as well tolerated at a $30 \mathrm{mg} \mathrm{b}$. i.d. dose for 6 weeks.

A pyrrolopyrimidine series of inhibitors have been reported to be inhibitors of JAK3 [56]. Compound 25, for example, inhibited JAK3 with $\mathrm{IC}_{50}=142 \mathrm{nM}$ and IL-4induced TF-1 cell proliferation with $\mathrm{IC}_{50}=140 \mathrm{nM}$. The selectivity of this series of compounds over JAK2 was modest at best in the enzyme as well as cell assays. A series of pyrimidines with a similar activity and selectivity profile has been reported [57]. Compound 26 inhibited JAK3 with $\mathrm{IC}_{50}=45 \mathrm{nM}$ and inhibited IL-4-induced proliferation of TF-1 cells with $\mathrm{IC}_{50}=90 \mathrm{nM}$. A staurosporine analog, 27, inhibited JAK3 with $\mathrm{IC}_{50}=31 \mathrm{nM}$ [58]. This series of compounds lacked a desirable solubility profile and additional data were not disclosed.<smiles>CN1CCN(C(=O)c2cc3c(NC(C)(C)C(C)(C)O)nc(-n4cnc5ccncc54)nc3n2C)CC1</smiles>

25<smiles>COC[C@@H](O)Nc1ccnc(-n2cnc3ccc(C#N)cc32)n1</smiles>

26<smiles></smiles>

27<smiles>CC1CCN(P)CC1N(C)c1ncnc2[nH]ccc12</smiles>

PF-956,980<smiles>C[C@H]1CCN(C(=O)CC#N)C[C@H]1N(C)c1ncnc2[nH]ccc12</smiles>

CP-690,550

Fig. 4 JAK3 inhibitors 


\section{Concluding remarks}

Discovery of kinase inhibitors for the treatment of inflammation and autoimmune disorders has been ongoing for almost two decades now. Drugs targeting p38 kinase for the treatment of arthritis and other autoimmune diseases have progressed to phase III clinical trials, but have not been found to be suitable for filing for registration. A number of drugs targeting the kinases p38, JNK, MEK, IKK2, JAK3, Lck, and Syk are currently undergoing clinical trials for the treatment of diseases related to inflammation and autoimmunity. It is anticipated that some of these or newer ones will be found suitable for the treatment of rheumatoid arthritis, psoriasis, organ transplantation, or other immune disorders.

\section{References}

1. Goldstein DM, Gray NS, Zarrinkar PP (2008) High-throughput kinase profiling as a platform for drug discovery. Nat Rev Drug Discov 7:391-397

2. Karaman MW, Herrgard S, Treiber DK et al (2008) A quantitative analysis of kinase inhibitor selectivity. Nat Biotechnol 26:127132

3. Bhagwat SS (2007) MAP kinase inhibitors in inflammation and autoimmune disorders. Ann Rep Med Chem 42:265-278

4. Strnad J, Burke JR (2007) IKB kinase inhibitors for treating autoimmune and inflammatory disorders: potential and challenges. Trends Pharmacol Sci 28:142-148

5. Lavon I, Goldberg I, Amit S et al (2000) High susceptibility to bacterial infection, but no liver dysfunction, in mice compromised for hepatocyte NF-kB activation. Nat Med 6:573-577

6. Burke JR, Pattoli MA, Gregor KR et al (2003) BMS-345541 is a highly selective inhibitor of IKB kinase that binds at an allosteric site of the enzyme and blocks NF-kB-dependent transcription in mice. J Biol Chem 278:1450-1456

7. MacMaster JF, Dambach DM, Lee DB et al (2003) An inhibitor of I $\mathrm{B}$ kinase, BMS-345541, blocks endothelial cell adhesion molecule expression and reduces the severity of dextran sulfate sodium-induced colitis in mice. Inflamm Res 52:508-511

8. Beaulieu F, Ouellet C, Ruediger EH et al (2007) Synthesis and biological evaluation of 4-amino derivatives of benzimidazoquinoxaline, benzimidazoquinoline, and benzopyrazoloquinazoline as potent IKK inhibitors. Bioorg Med Chem Lett 17:1233-1237

9. Belema M, Bunker A, Nguyen VN et al (2007) Synthesis and structure-activity relationship of imidazo(1,2-a)thieno(3,2-e)pyrazines as IKK- $\beta$ inhibitors. Bioorg Med Chem Lett 17:4284-4289

10. Bingham AH, Davenport RJ, Gowers L et al (2004) A novel series of potent and selective IKK2 inhibitors. Bioorg Med Chem Lett 14:409-412

11. Murata T, Shimada M, Sakakibara S et al (2004) Synthesis and structure-activity relationships of novel IKK- $\beta$ inhibitors. Part 3: orally active anti-inflammatory agents. Bioorg Med Chem Lett 14:4019-4022

12. Murata T, Shimada M, Kadono H et al (2004) Synthesis and structure-activity relationships of novel IKK-beta inhibitors. Part 2: improvement of in vitro activity. Bioorg Med Chem Lett $14: 4013-4018$
13. Murata T, Shimada M, Sakakibara S et al (2003) Discovery of novel and selective IKK-serine-threonine protein kinase inhibitors. Bioorg Med Chem Lett 13:913-916

14. Ziegelbauer K, Gantner F, Lukas NW et al (2005) A selective novel low-molecular-weight inhibitor of IKB kinase- $\beta$ (IKK- $\beta$ ) prevents pulmonary inflammation and slows broad anti-inflammatory activity. Br J Pharmacol 145:178-192

15. Kishore N, Sommers C, Mathialagan S et al (2003) A selective IKK-2 inhibitor blocks NF-KB-dependent gene expression in interleukin-1b-stimulated synovial fibroblasts. J Biol Chem 278:32861-32871

16. Bonafoux D, Bonar S, Christine L et al (2005) Inhibition of IKK2 by 2-[(aminocarbonyl)amino]-acetylenyl-3-thiophenecarboxamides. Bioorg Med Chem Lett 15:2870-2875

17. Podolin PL, Callahan JF, Bolognese BJ et al (2005) Attenuation of murine collagen-induced arthritis by a novel, potent, selective small molecule inhibitor of IKB kinase 2, TPCA-1 (2-[(aminocarbonyl)amino]-5-(4-fluophenyl)-3-thiophenecarboxamide), occurs via reduction of proinflammatory cytokines and antigeninduced T cell proliferation. J Pharmacol Exp Ther 312:373-381

18. Baxter A, Brough S, Cooper A et al (2004) Hit-to-lead studies: the discovery of potent, orally active, thiophenecarboxamide IKK-2 inhibitors. Bioorg Med Chem Lett 14:2817-2822

19. Waelchli R, Bollbuck B, Bruns C et al (2006) Design and preparation of 2-benzamido-pyrimidines as inhibitors of IKK. Bioorg Med Chem Lett 16:108-112

20. Bhagwat SS, Bennett BL, Satoh Y et al (2001) The small molecule IKK2 inhibitor SPC-839 is efficacious in an animal model of arthritis. A paper presented at ACR Annual Scientific Meeting, San Francisco

21. Frelin C, Imbert V, Greissinger E et al (2003) AS602868, a pharmacological inhibitor of IKK2, reveals the apoptotic potential of TNF- $\alpha$ in Jurkat leukemic cells. Oncogene 22:8187-8194

22. Castro AF, Dang LC, Soucy F et al (2003) Novel IKK inhibitors: $\beta$-carbolines. Bioorg Med Chem Lett 13:2419-2422

23. Wong BR, Grossbard EB, Payan DG, Masuda ES (2004) Targeting Syk as a treatment for allergic and autoimmune disorders. Expert Opin Investig Drugs 13:743-762

24. Lai JYQ, Cox PJ, Patel R et al (2003) Potent small molecule inhibitors of spleen tyrosine kinase (Syk). Bioorg Med Chem Lett 13:3111-3114

25. Cywin CL, Zhao B-P, McNeil DW et al (2003) Discovery and SAR of novel $[1,6]$ naphthyridines as potent inhibitors of spleen tyrosine kinase (SYK). Bioorg Med Chem Lett 13:1415-1418

26. Yamamoto N, Takeshita K, Shichijo M et al (2003) The orally available spleen tyrosine kinase inhibitor 2-[7-(3,4-dimethoxyphenyl)-imidazo[1,2-c]pyrimidin-5-ylamino]-nicotinamide dihydrochloride (BAY 61-3606) blocks antigen-induced airway inflammation in rodents. J Pharmacol Exp Ther 306:1174-1181

27. Hisamichi H, Naito R, Toyoshima A et al (2005) Synthetic studies on novel Syk inhibitors. Part 1: synthesis and structure-activity relationships of pyrimidine-5-carboxamide derivatives. Bioorg Med Chem 13:4936-4949

28. Rossi AB, Herlaar E, Braselmann S et al (2006) Identification of the Syk kinase inhibitor R112 by a human mast cell screen. J Allergy Clin Immunol 118:749-755

29. Meltzer EO, Berkowitz RB, Grosshead EB (2005) An intranasal Syk-kinase inhibitor (R112) improves the symptoms of seasonal allergic rhinitis in a park environment. J Allergy Clin Immunol 115:791-796

30. Braselman S, Taylor V, Zhao H et al (2006) R406, an orally available spleen tyrosine kinase inhibitor blocks fc receptor signaling and reduces immune complex-mediated inflammation. J Pharmacol Exp Ther 319:998-1008 
31. Pine PR, Chang B, Schoettler N et al (2007) Inflammation and bone erosion are suppressed in models of rheumatoid arthritis following treatment with a novel Syk inhibitor. Clin Immunol 124:244-257

32. Kamens JS, Ratnofsky SE, Hirst GC et al (2001) Lck inhibitors as a therapeutic approach to autoimmune disease and transplant rejection. Curr Opin Investig Drugs 2:1213-1219

33. Bamborough P, Angell RM, Bhamra I et al (2007) N-4Pyrimidinyl-1H-indazol-4-amine inhibitors of Lck: indazoles as phenol isosteres with improved pharmacokinetics. Bioorg Med Chem Lett 17:4363-4368

34. Di Mauro EF, Newcomb J, Nunes JJ et al (2007) Discovery of 4amino-5,6-biaryl-furo[2,3-d]pyrimidines as inhibitors of Lck: development of an expedient and divergent synthetic route and preliminary SAR. Bioorg Med Chem Lett 17:2305-2309

35. Martin MW, Newcomb J, Nunes JJ et al (2007) Discovery of novel 2,3-diarylfuro[2,3-b]pyridine-4-amines as potent and selective inhibitors of Lck: synthesis, SAR, and pharmacokinetic properties. Bioorg Med Chem Lett 17:2299-2304

36. Abbott L, Betschmann P, Burchat A et al (2007) Discovery of thienopyridines as Src-family selective Lck inhibitors. Bioorg Med Chem Lett 17:1167-1171

37. Burchat A, Borhani DW, Calderwood DJ et al (2006) Discovery of A-770041, a src-family selective orally active lck inhibitor that prevents organ allograft rejection. Bioorg Med Chem Lett 16: $118-122$

38. Mukaiyama H, Nishimura T, Kobayashi S et al (2007) Synthesis and c-Src inhibitory activity of imidazo[1,5-a]pyrazine derivatives as an agent for the treatment of acute ischemic stroke. Bioorg Med Chem 15:868-885

39. Noronha G, Barrett K, Boeccia A et al (2007) Discovery of [7(2,6-dichlorophenyl)-5-methylbenzo[1,2,4]triazin-3-yl]-[4-(2-pyrrolidin-1-ylethoxy)phenyl]-amine - a potent, orally active Src kinase inhibitor with anti-tumor activity in preclinical assays. Bioorg Med Chem Lett 17:602-608

40. Sabat M, VanRens JC, Laufersweiler MJ et al (2006) The development of 2-benzimidazole substituted pyrimidine based inhibitors of lymphocyte specific kinase (Lck). Bioorg Med Chem Lett 16:5973-5977

41. Sabat M, VanRens JC, Brugel TA et al (2006) The development of novel 1,2-dihydro-pyrimido[4,5-c]pyridazine based inhibitors of lymphocyte specific kinase (Lck). Bioorg Med Chem Lett 16:4257-4261

42. Maier JA, Brugel TA, Sabat M et al (2006) Development of N4,6-pyrimidine-N-alkyl-N'-phenyl ureas as orally active inhibitors of lymphocyte specific tyrosine kinase. Bioorg Med Chem Lett 16:3646-3650

43. Das J, Chen P, Norris D et al (2006) 2-aminothiazole as a novel kinase inhibitor template. Structure-activity relationship studies toward the discovery of $\mathrm{N}$-(2-chloro-6-methylphenyl)-2-[[6-[4-(2hydroxyethyl)-1-piperazinyl)]-2-methyl-4-pyrimidinyl]amino)] 1,3-thiazole-5-carboxamide (dasatinib, BMS-345825) as a potent pan-Src kinase inhibitor. J Med Chem 49:6819-6832

44. DiMauro EF, Newcomb J, Nunes JJ et al (2006) Discovery of aminoquinazolines as potent, orally bioavailable inhibitors of Lck: synthesis, SAR, and in vivo anti-inflammatory activity. J Med Chem 49:5671-5686

45. Cetkovic-Cvrlje M, Tibbles HE (2004) Therapeutic potential of Janus kinase 3 (JAK3) inhibitors. Curr Pharm Des 10:1767-1784

46. Notarangelo LD, Giliani S, Mazza C et al (2000) Of genes and phenotypes: the immunological and molecular spectrum of combined immune deficiency. Defects of the $\gamma \mathrm{c}$-JAK3 signaling pathways as a model. Immunol Rev 178:39-48

47. Suzuki K, Nakajima H, Saito Y et al (2000) Janus kinase 3 (Jak3) is essential for common cytokine receptor $\gamma$ chain $(\gamma \mathrm{c})$-dependent signaling: comparative analysis of $\gamma \mathrm{c}$, Jak3, and $\gamma \mathrm{c}$ and Jak3 double-deficient mice. Int Immunol 12:123-132

48. Vassilev AO, Tibbles H, DuMez D et al (2006) Targeting JAK3 and BTK tyrosine kinases with rationally-designed inhibitors. Curr Drug Targets 7:327-343

49. Deuse T, Velotta JB, Hoyt G et al (2008) Novel immunosuppression: R348, a JAK3- and Syk-inhibitor attenuates acute cardiac allograft rejection. Transplantation 85:885-892

50. Changelian PS, Moshinsky D, Kuhn CF et al (2008) The specificity of JAK3 kinase inhibitors. Blood 111:2155-2157

51. Changelian PS, Flanagan ME, Ball DJ et al (2003) Prevention of organ allograft rejection by a specific Janus kinase 3 inhibitor. Science 302:875-878

52. Kudlacz E, Perry B, Sawyer P et al (2004) The novel JAK3 inhibitor CP-690550 is a potent immunosuppressive agent in various murine models. Am J Transplant 4:51-57

53. Milici A, Kudlacz EM, Audoly L et al (2008) Cartilage preservation by inhibition of Janus kinase 3 in two rodent models of rheumatoid arthritis. Arthritis Res Ther 10:R14

54. Kremer JM, Bloom BJ, Breedveid FC et al (2006) A randomized, double-blind, placebo-controlled trial of 3 dose levels of CP690,550 versus placebo in the treatment of active rheumatoid arthritis (abstract L40). Presented at the American College of Rheumatology Annual Meeting, November 2006, Washington DC

55. Busque S, Leventhal J, Brennan D et al (2007) CP-690,550 (CP), a JAK3 inhibitor, in de novo kidney transplant (KT) recipients: 6-month results of a phase 2 trial (abstract). Am J Transplant 2:304

56. Clark MP, George KM, Bookland RG et al (2007) Development of new pyrrolopyrimidine-based inhibitors of Janus kinase 3 (JAK3). Bioorg Med Chem Lett 17:1250-1253

57. Chen JJ, Thakur KD, Clark MP et al (2006) Development of pyrimidine-based inhibitors of Janus tyrosine kinase 3. Bioorg Med Chem Lett 17:5633-5638

58. Yang S-M, Malaviya R, Wilson LJ et al (2007) Simplified staurosporine analogs as potent JAK3 inhibitors. Bioorg Med Chem Lett 17:326-331 